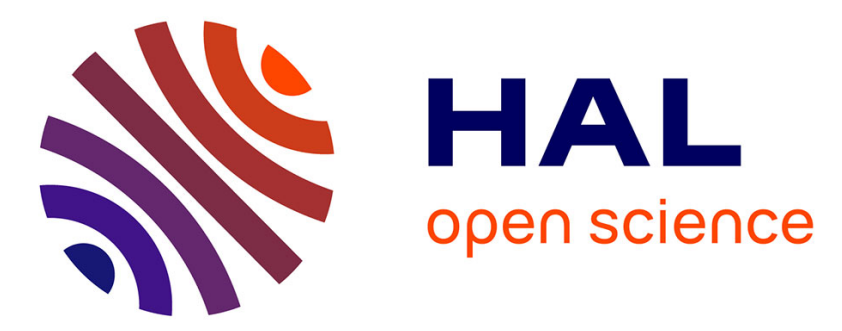

\title{
Coumarins and other constituents from Deverra battandieri
}

\author{
C. Esseid, F. León, Paul Mosset, S. Benayache, E. Marchioni, I. Brouard, F. \\ Benayache
}

\section{- To cite this version:}

C. Esseid, F. León, Paul Mosset, S. Benayache, E. Marchioni, et al.. Coumarins and other constituents from Deverra battandieri. Phytochemistry Letters, 2021, 42, pp.129-133. 10.1016/j.phytol.2020.08.013 . hal-03122729

\section{HAL Id: hal-03122729 \\ https://hal.science/hal-03122729}

Submitted on 16 Feb 2021

HAL is a multi-disciplinary open access archive for the deposit and dissemination of scientific research documents, whether they are published or not. The documents may come from teaching and research institutions in France or abroad, or from public or private research centers.
L'archive ouverte pluridisciplinaire HAL, est destinée au dépôt et à la diffusion de documents scientifiques de niveau recherche, publiés ou non, émanant des établissements d'enseignement et de recherche français ou étrangers, des laboratoires publics ou privés. 


\section{Coumarins and other constituents from Deverra battandieri}

Chahrazed Esseid ${ }^{\mathrm{a}}$, Francisco León ${ }^{\mathrm{b}, \mathrm{c}, *}$, Paul Mosset ${ }^{\mathrm{d}}$, Samir Benayache ${ }^{\mathrm{a}}$, Eric Marchionie, Ignacio Brouard ${ }^{\mathrm{b}}$, Fadila Benayache ${ }^{\mathrm{a}, *}$

${ }^{a}$ Unité de recherche Valorisation des Ressources Naturelles, Molécules Bioactives et Analyses Physicochimiques et Biologiques. Université Frères Mentouri, Constantine 1, Route d'Aïn El Bey, 25000, Constantine, Algérie

${ }^{b}$ Instituto de Productos Naturales y Agrobiología-C.S.I.C., Av. Astrofisico F. Sánchez 3, 38206 La Laguna, Tenerife, Spain

${ }^{c}$ Department of Drug Discovery and Biomedical Science, College of Pharmacy, Columbia, South Carolina, 29208, United States

${ }^{d}$ Univ Rennes, CNRS, ISCR (Institut des Sciences Chimiques de Rennes), UMR 6226, F-35000

Rennes, France

${ }^{e}$ Chimie Analytique des Molécules Bioactives, Institut Pluridisciplinaire Hubert Curien (UMR 7178

CNRS/UDS), 74 route du Rhin, 67400 Illkirch, France

*Corresponding authors.

E-mail addresses: ileon@mailbox.sc.edu (F.Leon), bbenavache@yahoo.fr (F.Benayache) 


\section{ABSTRACT}

Three undescribed coumarin derivatives, pituranthosin A-C (1-3), along with nineteen known compounds were isolated and identified from the chloroform and ethyl acetate fractions of the hydroalcoholic extract of Deverra battandieri (Apiaceae). The structures of the compounds were established by interpretation of their spectral data using $1 \mathrm{D}-\mathrm{NMR}\left({ }^{1} \mathrm{H},{ }^{13} \mathrm{C}\right.$, DEPT experiments), 2D-NMR (COSY, NOESY, HSQC and HMBC), HRESIMS, and by comparison with the literature data.

Keywords.

Apiaceae, Deverra battandieri, coumarin, furanocoumarin, Saharan medicinal plants 


\section{Introduction}

The members of the Apiaceae family are well-known producers of coumarins (Caesar and Cech, 2016; Matos et al., 2015) and furanocoumarins (Dueholm et al., 2015; Sarker and Nahar, 2017; Bruni et al., 2019). Coumarins are recognized to exhibit valuable biological properties such as analgesic, anti-inflammatory, antibacterial, antiviral, antifungal, and antiproliferative (Dehghan et al., 2017; Hashita and Dharmesh, 2018; Hassan et al., 2016; Song et al., 2017; Zhu and Jiang, 2018), apart from their well-known photosensitizing properties (Kasperkiewicz et al., 2016). The genus Deverra D.C. (Apiaceae) is spread in the Mediterranean region including the Arabic peninsula; it consists of seventeen species of which nine are accepted (Dobignard and Chatelain, 2011; Downie et al., 2010). Several members of the Deverra genus are used in folk medicine to treat asthma, rheumatism, digestive difficulties, urinary infections, and scorpion stings (Attia et al., 2011; Benchelah et al., 2000; Boukef, 1986; Guetat et al., 2019; Hammiche and Maiza, 2006). Deverra battandieri (Maire) Podlech [syn. Pituranthos battandieri (Maire)] is a traditional medicinal plant and a native species of the Sahara Desert of North Africa, particularly in Morocco and Algeria (Quezel and Santa, 1963; El Oualidi et al., 2012). Previously, antioxidant properties and phytochemical study on the polar fractions of D. battandieri led to the isolation of coumarins: xanthotoxol, 8-(6', $7^{\prime}$-dihydroxygeranyloxy)psoralen, the flavonoid: isorhamnetin 3-O-ß-D-glucopyranoside, and mannitol (Esseid et al., 2017).

Following a systematic study of Saharan medicinal plants collected in Algeria (Boumaraf et al., 2017; Hammoud et al., 2018), this report describes the isolation and structural elucidation of three previously undescribed coumarin derivatives (1-3) (Figure 1), nine known coumarins (4-12) (Figure S1), and additional ten known compounds from extracts of $D$. battandieri collected in Bechar region of southern Algeria. 


\section{Results and discussion}

Purification of the chloroform $\left(\mathrm{CHCl}_{3}\right)$ and ethyl acetate (EtOAc) extracts of the hydroalcoholic (80:20) extract from the aerial parts of Deverra battandieri by column chromatography afforded three new furanocoumarin derivatives, pituranthosins A-C (1-3). The known furanocoumarins: 8-[(R)-6',7'-dihydroxygeranyloxy]psoralen (4) (Ito et al, 1998; Row et al, 2006), xanthotoxol (5) (He et al., 2007), xanthotoxin (6) (Harkar et al., 1984), (R)-(+)heraclenin (7) (Setzer et al., 2003), (R)-(+)-byakangelicol (8) (Setzer et al, 2003), $(R)-(+)-$ byakangelicin (9) (Ngwendson et al., 2003), phellopterin (10) (Kang et al., 2008); and the coumarins $(R)-(+)$-marmin (11) (Coates and Melvin, 1970) and rutaretin (12) (Lemmich and Shabana, 1984) were also isolated. Several other known compounds such as vanillin (Youssef and Frahm, 1995), vanillic acid (Kwon and Lee, 2001), $\beta$-hydroxypropiovanillone (Karonen et al., 2004), isorhamnetin (Spinola and Castilho, 2016), apigenin (Kouichi et al., 2011), and biochanin A (Agrawal and Bansal, 1989) were isolated along with the mixtures: stigmasterol and $\beta$-sitosterol (50-50\%) (Hammoud et al., 2018), daucosterol and stigmasterol 3-O- $\beta$ glucopyranoside (72-28\%) (Voutquene and Lavaud, 1999). The structures of these known compounds were confirmed by comparison of their spectroscopic data (MS and ${ }^{1} \mathrm{H}-$ and ${ }^{13} \mathrm{C}$ NMR) with the literature.

Pituranthosin A (1) was isolated as a yellowish powder and its molecular formula was determined as $\mathrm{C}_{23} \mathrm{H}_{28} \mathrm{O}_{6}$ by its pseudo molecular peak on positive HRESIMS $\mathrm{m} / z$ 423.1773 $[\mathrm{M}+\mathrm{Na}]^{+}$(calcd. for $\mathrm{C}_{23} \mathrm{H}_{28} \mathrm{O}{ }_{6} \mathrm{Na}, 423.17781$ ) indicating ten degrees of unsaturation. The ${ }^{1} \mathrm{H}$ NMR spectrum (Table 1) showed characteristic aromatic signals for two independent $A B$ systems at $\delta_{\mathrm{H}} 8.03(\mathrm{~d}, J=9.6 \mathrm{~Hz}, 1 \mathrm{H}), 6.38(\mathrm{~d}, J=9.6 \mathrm{~Hz}, 1 \mathrm{H})$, and $7.90(\mathrm{~d}, J=2.2 \mathrm{~Hz}, 1 \mathrm{H})$, $6.96(\mathrm{~d}, J=2.2 \mathrm{~Hz}, 1 \mathrm{H})$, and a singlet at $\delta_{\mathrm{H}} 7.57(\mathrm{~s}, 1 \mathrm{H}) \mathrm{ppm}$ indicating a psoralen type furanocoumarin nucleus (Adams et al., 2006). Additional ${ }^{1} \mathrm{H}$ NMR signals revealed the presence of two methyls on a quaternary carbon at $\delta_{\mathrm{H}} 1.10$ and $1.05 \mathrm{ppm}$, one methyl on a 
double bond at $\delta_{\mathrm{H}} 1.66(\mathrm{~s}, 3 \mathrm{H})$, one oxygenated methylene at $\delta_{\mathrm{H}} 5.03(\mathrm{~d} \mathrm{br}, J=6.9 \mathrm{~Hz}, 2 \mathrm{H})$, one oxygenated methine at $\delta_{\mathrm{H}} 3.26(\mathrm{dd}, J=10.5,1.8 \mathrm{~Hz}, 1 \mathrm{H})$, and two aliphatic methylenes among other signals, indicating the presence of a geranyl group as a substituent in the furanocoumarin core. Both the ${ }^{1} \mathrm{H}$ - and ${ }^{13} \mathrm{C}-\mathrm{NMR}$ (Tables 1 and 2) spectral data of compound 1 were close to those of 8-[(6',7'-dihydroxy-3',7'-dimethyl-2'-octenyl)oxy]psoralen (Ito et al., 1998) with additional ${ }^{1} \mathrm{H}-\mathrm{NMR}$ signals at $\delta_{\mathrm{H}} 3.40(\mathrm{qd}, J=7.0,1.7 \mathrm{~Hz}, 2 \mathrm{H})$ and $1.12(\mathrm{t}, J=7.0$ $\mathrm{Hz}, 3 \mathrm{H}) \mathrm{ppm}$ assignable to an ethoxyl group, which revealed that compound $\mathbf{1}$ was an $O$-ethyl derivative. To determine the position of the geranyl and ethoxyl groups, the HMBC (Figure 2) experiment was useful. Thus, connectivity observed between the protons of the signal at $\delta_{\mathrm{H}} 3.40$ ppm (qd, $J=7.0,1.7 \mathrm{~Hz}, 2 \mathrm{H})$ and the quaternary carbon at $\delta_{\mathrm{C}} 78.32$ helped us to situate the ethoxy group at $\mathrm{C}-7^{\prime}$. Besides, correlations between the protons in $\mathrm{C}-1^{\prime}$ at $\delta_{\mathrm{H}} 5.03(\mathrm{~d}$ br, $J=7.6$ $\mathrm{Hz}, 2 \mathrm{H})$ and $\mathrm{C}-8$ at $\delta_{\mathrm{C}} 132.29$, and between the proton at $\delta_{\mathrm{H}} 7.57(\mathrm{~s}, 1 \mathrm{H}, \mathrm{H}-5)$ and the carbons $\mathrm{C}-4\left(\delta_{\mathrm{C}} 146.75\right)$ and $\mathrm{C}-10\left(\delta_{\mathrm{C}} 107.96\right)$ led us to link the geranyl group at $\mathrm{C}-8$ position in the central core. The presence of the furanocoumarin nucleus was further supported by its ultraviolet (UV) spectrum which showed a typical absorption maximum at $310 \mathrm{~nm}$ due to aromatic $\pi-\pi^{*}$ transition. Being well-known that the psoralen derivatives are known to be potential photosensitizers (Kitamura et al, 2005) this observation is extensive to the undescribed furanocoumarin derivatives isolated from D. battandieri (Figure 3b). This Compound (1) was found optically active with $[\alpha]_{\mathrm{D}}^{20}+8.8 ;[\alpha]_{578}^{20}+9.7 ;[\alpha]_{546}^{20}+10.3$ (c 1.365 $\mathrm{g} / 100 \mathrm{ml}, \mathrm{MeOH})$. The positive value of the optical rotation agreed with the $(R)$ configuration of the chiral center at C-6' (Edegger et al., 2004; Wang et al., 2018). Therefore, the structure of 1 was determined to be 8-[(R)-6'-hydroxy-7'-ethoxygeranyloxy]psoralen.

Compound (2) was obtained as a yellowish solid with a molecular formula of $\mathrm{C}_{24} \mathrm{H}_{28} \mathrm{O}_{6}$ deduced from the positive HRESIMS $m / z$ 435.1780 $[\mathrm{M}+\mathrm{Na}]^{+}$(calcd. for $\mathrm{C}_{24} \mathrm{H}_{28} \mathrm{O}_{6} \mathrm{Na}$, 435.1784) and indicated eleven degrees of unsaturation in it. The ${ }^{1} \mathrm{H}-\mathrm{NMR}$ data (Table 1) of $\mathbf{2}$, 
was very similar to that of $\mathbf{1}$, suggesting that the two compounds were closely related in structure. The major difference is that $\mathbf{2}$ has two additional $\mathrm{C}$-methyl resonances and lacked the ethyl group. A detailed comparison of the ${ }^{1} \mathrm{H}$ - and ${ }^{13} \mathrm{C}$-NMR signals of $\mathbf{1}$ and $\mathbf{2}$ (Tables 1 and 2) revealed that the signals due to ethoxy group at $\delta_{\mathrm{H}} 3.40(\mathrm{qd}, J=7.0,1.7 \mathrm{~Hz}, 2 \mathrm{H})$ and $1.12(\mathrm{t}$, $J=7.0 \mathrm{~Hz}, 3 \mathrm{H}) \mathrm{ppm}$ of $\mathbf{1}$ have been replaced by signals due to an acetonide group seen at $\delta_{\mathrm{H}}$ $1.36(\mathrm{~s}, 3 \mathrm{H}), \delta_{\mathrm{C}} 28.90 ; \delta_{\mathrm{H}} 1.23(\mathrm{~s}, 3 \mathrm{H}), \delta_{\mathrm{C}} 27.15$, and $\delta_{\mathrm{C}} 107.64$. Thus, compound 2 was determined to be 8 -[6', $7^{\prime}$-dihydroxygeranyloxy]psoralen acetonide and was named pituranthos in B.

Compound (3) differs in the side chain at C-8 from compounds $\mathbf{1}$ and 2. Its UV spectrum showed a maximum absorption at $312 \mathrm{~nm}$ due to the characteristic aromatic $\pi$ - $\pi^{*}$ transition of furanocoumarins (Figure 3d) (Kitamura et al., 2005). The positive HRESIMS spectrum of 3 showed a pseudomolecular ion $[\mathrm{M}+\mathrm{Na}]^{+}$at $\mathrm{m} / \mathrm{z} 411.1419$ matching the molecular formula $\mathrm{C}_{21} \mathrm{H}_{24} \mathrm{O}_{7}$ (calcd for $\mathrm{C}_{21} \mathrm{H}_{24} \mathrm{O}_{7} \mathrm{Na}$ : 411.1420) and indicating a compound containing ten unsaturations. The NMR data of $\mathbf{3}$ (Tables 1 and 2) was similar to those of citraurancoumarin B, a furanocoumarin, with the presence of a 2,6,7-trihydroxy-7-methyl-3(10)-methyleneoctan1-oxy group at the C-5 position (Xiong et al., 2016). HMBC experiment of compound 3 allowed to identify the differences between compound $\mathbf{3}$ and citraurancoumarin B. Thus, HMBC correlations between the proton at position $\mathrm{C}-5\left(\delta_{\mathrm{H}} 7.59\right)$ with $\mathrm{C}-4\left(\delta_{\mathrm{C}} 146.75\right)$, and $\mathrm{C}-10\left(\delta_{\mathrm{C}}\right.$ $107.98)$ and the HMBC correlation between $\mathrm{C}-8\left(\delta_{\mathrm{C}} 132.97\right)$ and the protons of the oxygenated methylene $\mathrm{C}-1^{\prime}\left(\delta_{\mathrm{H}} 4.61-4.54,2 \mathrm{H}\right)$ confirmed the side chain at $\mathrm{C}-8$. The stereochemistry was not determined due to the small amount of compound isolated. Therefore, compound $\mathbf{3}$ was

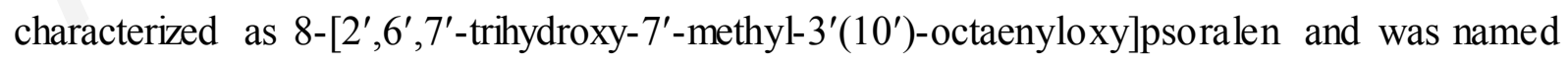
pituranthosin $\mathrm{C}$.

Initially, compound $\mathbf{1}$ seemed to be an artifact but during the isolation process and chromatographic separation, no ethanol solvent was used (see Experimental). Pituranthosin B 
$\mathbf{2}$ can be an artifact obtained from compound $\mathbf{4}$ and was generated with the use of acetone in the fractionation process. However, no harsh conditions were used in the isolation process of 2. The formation of $\mathbf{2}$ was not observed while incubating compound $\mathbf{4}$ with acetone for $24 \mathrm{~h}$. These facts suggested that compounds $\mathbf{1}$ and $\mathbf{2}$ are indeed undescribed secondary metabolites. The number of coumarins reported from Deverra species are few; for example, D. triradiata reported the presence of pituranthoside, S-trans-marmin, xanthotoxol, umbelliferone, isopimpinellin, and bergapten (Halim et al, 1995); D. deanudata reported the coumarins: bergapten, isoimperatorin, nodakenetin, osthol, and oxypeucedanin (Aloui et al., 2015), and the polar extracts of $D$. battandieri reported xanthotoxol and 8-(6',7'-dihydroxygeranyloxy)psoralen (Esseid et al., 2017). The high concentrations of coumarins found in this medicinal plant are potentially responsible for the wide variety of traditional benefits reported from this Saharan plant.

\section{Experimental}

\subsection{General Procedure}

Optical rotations were measured using a Perkin Elmer model 341. UV spectra were recorded using a Shimadzu model (190-3200 nm, UV-3101PC) or Shimadzu model UV-1700 spectrophotometer. ${ }^{1} \mathrm{H}$ - and ${ }^{13} \mathrm{C}-\mathrm{NMR}$ spectra were obtained by Bruker model Avance AMX-400 and AMX-500 MHz spectrometers (Bruker BioSpin, Rheinstetten, Germany) with standard pulse sequences operating at 400 and $500 \mathrm{MHz}$ for ${ }^{1} \mathrm{H}$ and 100 and $125 \mathrm{MHz}$ for ${ }^{13} \mathrm{C}$, respectively. MeOH- $d_{4}$, DMSO- $d_{6}$, or $\mathrm{CDCl}_{3}$ were used as solvents with TMS as internal standard. Chemical shifts $(\delta)$ are reported in ppm and coupling constants $(J)$ are reported in Hz. High resolution mass spectra (HRESIMS) were performed on an Agilent 6520 Accurate Mass Q-TOF (Agilent Corporation, Santa Clara, CA, USA), a $\mu$-QToF spectrometer (Bruker Daltonics, Wissembourg, France) with a LCT Premier XE Micromass Waters spectrometer in positive ionization mode (Waters Corporation) and a Bruker Maxis 4G (CRMPO Université de 
Rennes 1). Column chromatography (CC) were carried out with silica gel Fluka (cat. 60737, 40-63 $\mu \mathrm{m}$ ), silica gel 60 (Merck 230-400 mesh) and Sephadex LH-20 (Sigma-Aldrich). Column fractions were monitored by TLC silica gel $60 \mathrm{~F}_{254}$ (Merck), $0.2 \mathrm{~mm}$, Macherey Nagel (cat. 818-333) by detection with a spraying reagent $\mathrm{CH}_{3} \mathrm{CO}_{2} \mathrm{H}-\mathrm{H}_{2} \mathrm{O}-\mathrm{H}_{2} \mathrm{SO}_{4}$ (80:16:4) followed by heating at $100{ }^{\circ} \mathrm{C}$. Preparative TLC was carried out on silica gel $60 \mathrm{PF}_{254+366}(20 \mathrm{~cm} \times 20$ cm, $1 \mathrm{~mm}$ thickness, Analtech cat. 02014). Solvents such as $\mathrm{CHCl}_{3}$, toluene, EtOAc, and $\mathrm{MeOH}$ are reagent grade and were purchased from VWR (Fontenay-sous-bois, France); acetonitrile is HPLC grade and was purchased from Fisher Scientific; Milli-Q water (18.2 M $\Omega$ ) was generated by Millipore synergy System (Molsheim, France).

\subsection{Plant material}

The aerial parts from Deverra battandieri (Maire) Podlech [syn. Pituranthos battandieri Maire] (Quezel and Santa, 1963; Ozenda, 1958; El Oualidi et al., 2012), an endemic species of the Algerian-Moroccan Sahara, were harvested near the hydraulic dam of Djorf Torba in the Wilaya of Bechar in Southern Algeria (GPS coordinates $30^{\circ} 31^{\prime} 0^{\prime \prime} \mathrm{N}$ and $2^{\circ} 45^{\prime} 0^{\prime \prime} \mathrm{W}$ ) during the flowering stage in April 2010. The plant material was authenticated by M. Mohamed Benabdelhakem, Director of the nature preservation agency, Bechar. A voucher specimen (PBA 54/04/10) was deposited at the Herbarium of the VARENBIOMOL Research Unit, University Frères Mentouri Constantine 1.

\subsection{Extraction and isolation}

Air-dried aerial parts $(3350 \mathrm{~g})$ of $D$. battandieri Maire (Apiaceae) were macerated three times $(1000 \mathrm{ml} / \mathrm{each})$ at room temperature with $\mathrm{MeOH}-\mathrm{H}_{2} \mathrm{O}(80: 20, v / v)$ for $48 \mathrm{~h}$. After filtration, the filtrate was concentrated to reach a volume for around $1000 \mathrm{ml}$, then it was added additional $\mathrm{H}_{2} \mathrm{O}(1300 \mathrm{ml})$. The resulting solution was extracted successively with petroleum ether, $\mathrm{CHCl}_{3}, \mathrm{EtOAc}$, and $n$-BuOH. The organic layers were dried with $\mathrm{Na}_{2} \mathrm{SO}_{4}$, filtered, and 
concentrated in vacuum up to $35^{\circ} \mathrm{C}$ to obtain the following partition extracts: petroleum ether (0.9 g), $\mathrm{CHCl}_{3}(17 \mathrm{~g})$, EtOAc (12 g), and $n$ - $\mathrm{BuOH}(70 \mathrm{~g})$, respectively. The $\mathrm{CHCl}_{3}$ extract was fractionated by column chromatography (230-400 mesh silica gel; $n$-hexane-EtOAc step gradients, and then with increasing percentages of acetone) to give 31 fractions $\left(F_{1}-F_{31}\right)$ which were obtained by combining the fractions based on TLC analysis. Following purification of fraction $\mathrm{F}_{3}(150.4 \mathrm{mg})$ ( $n$-hexane/EtOAc $\left.88: 12\right)$ by crystallization in $\mathrm{MeOH}$ and a little amount of $\mathrm{CHCl}_{3}$, a mixture of $\beta$-sitosterol and stigmasterol (50-50\%) (27 mg) was isolated. Fraction F9 (276.8 mg) (n-hexane/EtOAc 80:20) was chromatographed on a silica gel column ( $n$ hexane/EtOAc 7:3) to yield 16 sub-fractions $\left(\operatorname{subF}_{1}-\mathrm{subF}_{16}\right) . \mathrm{SubF}_{11} \quad(50 \mathrm{mg})$ was chromatographed on preparative silica gel $\mathrm{TLC}\left(\mathrm{CHCl}_{3} 100 \%\right.$; two elutions) to afford xanthotoxin (6) (4 mg), phellopterin (10) (5 mg), and vanillin (8 mg). Fraction $\mathrm{F}_{11}(75.1 \mathrm{mg})$ ( $n$-hexane/EtOAc 78:22) was chromatographed on preparative silica gel TLC $\left(\mathrm{CHCl}_{3} /\right.$ acetone 19:1) to afford xanthotoxol (5) $(30.8 \mathrm{mg})$. Purification of fraction $\mathrm{F}_{13}(280 \mathrm{mg})$ (nhexane/EtOAc $70: 30)$ on preparative plates of silica gel $\left(\mathrm{CHCl}_{3} /\right.$ acetone $\left.19: 1\right)$ yielded 8 -[(R)6'-hydroxy-7'-ethoxygeranyloxy] psoralen named pituranthosin A (1) (7 mg). Fraction $\mathrm{F}_{18}(1.5$ g) (n-hexane/EtOAc 50:50) was chromatographed on a silica gel column ( $n$-hexane/EtOAc) to yield 27 sub-fractions ( $\left.\mathrm{subF}_{1}-\mathrm{subF}_{27}\right) . \mathrm{SubF}_{6}(62 \mathrm{mg})$ ( $n$-hexane/EtOAc 85:15) was subjected to preparative plates of silica gel TLC $\left(\mathrm{CHCl}_{3} /\right.$ acetone 98:2) to afford 8-[6', $7^{\prime}-$ dihydroxygeranyloxy]psoralen acetonide named pituranthosin $\mathrm{B}(2)(8 \mathrm{mg})$. $\mathrm{SubF}_{21}(45 \mathrm{mg})(n$ hexane/EtOAc 50:50) was chromatographed using preparative plates of silica gel TLC $\left(\mathrm{CHCl}_{3} /\right.$ acetone 9:1) and purified on a Sephadex LH-20 column to yield $(R)-(+)$-marmin $(\mathbf{1 1})$ (9 mg), (R)-(+)-heraclenin (7) (11 mg), and rutaretin (12) (8 mg). SubF24 (32 mg) (nhexane/EtOAc 30:70) gave $(R)-(+)$-byakangelicol (8) $(10 \mathrm{mg})$ after purification by crystallization in $\mathrm{MeOH}$. Fraction $\mathrm{F}_{20}(766 \mathrm{mg})$ (n-hexane/EtOAc 45:55) yielded, $(R)-(+)-$ byakangelicin (9) (536.5 mg) after purification by crystallization in $\mathrm{MeOH} / \mathrm{CHCl}_{3}$. Fraction $\mathrm{F}_{24}$ 
(184.5 mg) (n-hexane/EtOAc 20:80) gave 8-[2,6,7-trihydroxy-7-methyl-3(10)octaenyloxy]psoralen named pituranthosin C (3) (2 mg) after purification on preparative plates of silica gel ( $\mathrm{CHCl}_{3} /$ acetone 9:1 three elutions). The concentration of fraction $\mathrm{F}_{25}(543.8 \mathrm{mg})$ ( $n$-hexane/EtOAc 15:85) yielded a yellowish precipitate which was washed with $\mathrm{CHCl}_{3} / \mathrm{MeOH}$ to give a mixture of daucosterol and stigmasterol $3-O-\beta$-glucopyranoside at 72 and $28 \%$, respectively $(158 \mathrm{mg})$. The EtOAc extract $(10 \mathrm{~g})$ was chromatographed on a silica gel column (230-400 mesh silica gel; $\mathrm{CHCl}_{3}$-acetone step gradients and then with increasing percentages of $\mathrm{MeOH})$ to yield 43 fractions $\left(\mathrm{F}_{1}-\mathrm{F}_{43}\right)$ based on their TLC behavior. Fraction $\mathrm{F}_{9}(99 \mathrm{mg})$ $\left(\mathrm{CHCl}_{3} /\right.$ acetone $\left.98: 2\right)$ was subjected to preparative $\mathrm{TLC}$ on silica gel $\left(\mathrm{CHCl}_{3} /\right.$ acetone 9:1 two elutions) to give isorhamnetin $(20 \mathrm{mg})$. Fraction $\mathrm{F}_{11}(173 \mathrm{mg})\left(\mathrm{CHCl}_{3} /\right.$ acetone $\left.93: 7\right)$ was submitted to preparative silica gel TLC $\left(\mathrm{CHCl}_{3} /\right.$ acetone 9:1) and purified over Sephadex LH20 column eluted with $\mathrm{MeOH}$ to afford vanillic acid $(7 \mathrm{mg})$ and $\beta$-hydroxypropiovanillone (4.5 mg). Fraction $\mathrm{F}_{14}(148 \mathrm{mg})\left(\mathrm{CHCl}_{3} /\right.$ acetone $\left.90: 10\right)$ gave apigenin $(10 \mathrm{mg})$ after purification on preparative plates of silica gel $\left(\mathrm{CHCl}_{3} /\right.$ acetone $\left.9: 1\right)$. Fraction $\mathrm{F}_{17}(71 \mathrm{mg})\left(\mathrm{CHCl}_{3} /\right.$ acetone 88:12) was submitted to preparative plates of silica gel TLC $\left(\mathrm{CHCl}_{3} /\right.$ acetone $\left.9: 1\right)$ and purified on a Sephadex LH-20 column to afford 8-[(R)-6', $7^{\prime}$-dihydroxygeranyloxy]psoralen (4) (9 mg). Biochanin A (10 mg) was obtained from fraction $\mathrm{F}_{21}(124 \mathrm{mg})\left(\mathrm{CHCl}_{3} /\right.$ acetone $\left.85: 15\right)$ following purification on preparative silica gel plates $\left(\mathrm{CHCl}_{3} /\right.$ acetone $\left.8: 2\right)$.

8-[(R)-6'-hydroxy-7'-ethoxygeranyloxy]psoralen (1): yellow powder; $[\alpha]_{\mathrm{D}}^{20}+8.8$ (c 1.3 , $\mathrm{MeOH}) ;{ }^{1} \mathrm{H}-\mathrm{NMR}\left(400 \mathrm{MHz}, \mathrm{MeOH}-d_{4}\right)$ and ${ }^{13} \mathrm{C}-\mathrm{NMR}\left(100 \mathrm{MHz}, \mathrm{MeOH}-d_{4}\right)$ spectroscopic data, see Tables 1 and 2; HRESIMS m/z: $423.1773[\mathrm{M}+\mathrm{Na}]^{+}$(calcd for $\mathrm{C}_{23} \mathrm{H}_{28} \mathrm{NaO}_{6}$, 423.17781), m/z: $439.1515[\mathrm{M}+\mathrm{K}]^{+}\left(\right.$calcd for $\left.\mathrm{C}_{23} \mathrm{H}_{28} \mathrm{KO}_{6}, 439.15175\right)$. 
8 -[6', $7^{\prime}$-dihydroxygeranyloxy]psoralen acetonide (2): yellow powder; $[\alpha]_{\mathrm{D}}^{25} \quad 0 \quad$ (c 0.5 , $\left.\mathrm{CH}_{2} \mathrm{Cl}_{2}\right) ;{ }^{1} \mathrm{H}-\mathrm{NMR}\left(\mathrm{MeOH}-d_{4}, 500 \mathrm{MHz}\right)$ and ${ }^{13} \mathrm{C}-\mathrm{NMR}\left(\mathrm{MeOH}-d_{4}, 125 \mathrm{MHz}\right)$ spectroscopic data, see Tables 1 and 2; HRESIMS $m / z$ : $435.1780[\mathrm{M}+\mathrm{Na}]^{+}$(calcd for $\mathrm{C}_{24} \mathrm{H}_{28} \mathrm{O}_{6} \mathrm{Na}, 435.1784$ ).

8-[2',6',7'-trihydroxy-7'-methyl-3'(10')-octaenyloxy]psoralen (3): yellow powder; ${ }^{1} \mathrm{H}-\mathrm{NMR}$ (400 MHz, MeOH- $\left.d_{4}\right) ;{ }^{13} \mathrm{C}-\mathrm{NMR}\left(100 \mathrm{MHz}, \mathrm{MeOH}-d_{4}\right)$ spectroscopic data, see Tables 1 and 2; HRESIMS m/z: $411.1419[\mathrm{M}+\mathrm{Na}]^{+}$(calcd for $\mathrm{C}_{21} \mathrm{H}_{24} \mathrm{O}_{7} \mathrm{Na}, 411.1420$ ).

\subsection{HPLC-UV profiling of the chloroform fraction of D. battandieri}

The HPLC system included a Beckman HPLC system with Beckman 507E auto sampler, a 126 solvent delivery module, 166 single wavelength detector with the serial number: KA1B3VW. The detection was performed at $275 \mathrm{~nm}$ for UV active components. The analysis was carried on a $\mathrm{C} 18$ nucleosil column $(5 \mu \mathrm{m}, 250 \times 4.6 \mathrm{~mm})$ which was protected by security guard cartridge and was maintained at a constant room temperature of $25^{\circ} \mathrm{C}$. The mobile phases consisted of eluent A: $0.1 \%$ formic acid in water, and eluent B: $\mathrm{MeOH}$. Gradient was applied (A:B, $10-70-70-10 \% \mathrm{MeOH})(0-10-20-21-33 \mathrm{~min})$. The total run time was $55 \mathrm{~min}$. The flow rate was kept at $1.0 \mathrm{~mL} / \mathrm{min}$ and the injection volume was $20 \mu \mathrm{L}$. Peak identity of the individual peaks was assigned by retention time (RT) values based on comparison with the standards and spiked authentic standard to the sample.

\section{Acknowledgments}

This work was carried out with the support of PCI program (Spain-Algeria Cooperation Project A1/035449/11) and Tassili program (France-Algeria Cooperation, project 12MDU856).

\section{References}


Adams, M., Ettl, S., Kunert, O., Wube, A.A., Haslinger, E., Bucar, F., Bauer, R., 2006. Antimycobacterial activity of geranylated furocoumarins from Tetradium daniellii. Planta Med. 72, 1132-1135.

Agrawal, P.K., Bansal, M.C., 1989. Isoflavonoids in carbon-13 NMR of flavonoids. Elsevier, Amsterdam, p. 183.

Aloui, L., Kossentini, M., Geoffroy-Rodier, C., Guillard, J., Zouari, S., 2015. Phytochemical investigation, isolation and characterization of coumarins from aerial parts and roots of Tunisian Pituranthos chloranthus (Apiaceae). Pharmacogn. Commun. 5, 237-243.

Attia, S., Grissa, K.L., Lognay, G., Heuskin, S., Mailleux, A.C., Hance, T., 2011. Chemical composition and acaricidal properties of Deverra scoparia essential oil (Araliales: Apiaceae) and blends of its major constituents against Tetranychus urticae (Acari: Tetranychidae). J. Econ. Entomol. 104, 1220-1228.

Benchelah, A.C., Bouziane, H., Maka, M., Ouahes, C., 2000. Fleurs du Sahara. Voyage ethnobotanique avec les Touaregs du Tassili. Ed. Ibis Press, Paris.

Boukef, M.K., 1986. Les plantes dans la médecine traditionnelle tunisienne, Agence de Cooperation Culturelle et Technique, 1, 228-30.

Boumaraf, M., Carbone, M., Ciavatta, M.L., Benyahia, S., Ameddah, S., Menad, A., Benayache, S., Benayache, F., Gavagnin, M., 2017. Exploring the bioactive terpene content of an Algerian plant of genus Pulicaria: first occurrence of the ent-series of asteriscunolides. J. Nat. Prod. 80, 82-89.

Bruni, R., Barreca D., Protti, M., Brighenti, V., Righetti, L., Anceschi, L., Mercolini, L., Benvenuti, S., Gattusso, G., Pellati, F., 2019. Botanical sources, chemistry, analysis, and biological activity of furanocoumarins of pharmaceutical interest. Molecules 24, 2163.

Caesar, L.K., Cech, N.B., 2016. A review of the medicinal uses and pharmacology of Ashitaba. Planta Med. 82, 1236-1245.

Coates, R.M., Melvin, L.S., 1970. Total synthesis of (+)-marmin and related coumarin monoterpenes. Tetrahedron 26, 5699-5706.

Dehghan, H., Sarrafi, Y., Salehi, P., Ebrahimi, S.N., 2017. A Glucosidase inhibitory and antioxidant activity of furanocoumarins from Heracleum persicum. Med. Chem. Res. 26, 849-855.

Dobignard A., Chatelain C., 2011. Index synonymique- Flore d'Afrique du Nord, Vol 2. Editions des Conservatoire et Jardin Botaniques, Geneva.

Downie, S.R., Spalik, K., Katz-Downie, D.S., Reduron, J-P., 2010. Major clades within Apiaceae subfamily Apioideae as inferred by phylogenetic analysis of nrDNA ITS sequences. Plant Div. Evol. 128, 111-136.

Dueholm, B., Krieger, C., Drew, D., Olry, A., Kamo, T., Taboureau, O., Weitzel, C., Bourgaud, F., Hehn, A., Simonsen, H.T., 2015. Evolution of substrate recognition sites (SRSs) in cytochromes P450 from Apiaceae exemplified by the CYP71AJ subfamily. BMC Evol. Biol. $15,122$.

Edegger, K., Mayer, S.F., Steinreiber, A., Faber, K., 2004. Chemo-enzymatic enantioconvergent asymmetric synthesis of $(R)-(+)$-marmin. Tetrahedron 60, 583-588.

El Oualidi, J., Khamar, H., Fennane, M., Ibn Tattou, M., Chauvet, S., Taleb, M.S., 2012. Checklist des endémiques et spécimens types de la flore vasculaire de l'Afrique du Nord. Document de l'Institut Scientifique 25, p.10. Université Mohammed V, Rabat, Morocco.

Esseid, C., Hamadou, M.H., Ameddah, S., Ahmed, M., Leon, F., Brouard, I., Marchioni, E., Benayache, S., Benayache, F., 2017. Chemical constituents and antioxidant activity of a polar extract from Pituranthos battandieri Maire. Int. J. Pharmacog. Phytochem Res. 9, 559566. 
Guetat, A., Boulila, A., Boussaid, M., 2019. Phytochemical profile and biological activities of Deverra tortuosa (Desf.) DC.: a desert aromatic shrub widespread in Northern region of Saudi Arabia. Nat. Prod. Res. 33, 2708-2713.

Halim, A.F., Saad, H.E.A., Lahloub, M.F., Ahmed, A.F., 1995. Pituranthoside from Pituranthos triradiatus. Phytochemistry 40, 927-929.

Hammiche, V., Maiza, K., 2006. Traditional medicine in Central Sahara: Pharmacopoeia of Tassili N'ajier. J. Ethnopharmacol. 105, 358-367.

Hammoud, L., León, F., Brouard, I., Gonzalez-Platas, J., Benayache S., Mosset, P., Benayache, F., 2018. Humulene derivatives from Saharian Asteriscus graveolens. Tetrahedron Lett. 59, 2668-2670.

Harkar, S., Razdan, T.K., Waight, E.S., 1984. Steroids, chromone and coumarins from Angelica officinalis. Phytochemistry 23, 419-426.

Hashita, P., Dharmesh, S.M., 2018. Antioxidant and anti-inflammatory properties of marmelosin from Bael (Aegle marmelos L.); inhibition of TNF- $\alpha$ mediated inflammatory/tumor markers. Biomed. Pharmacother. 106, 98-108.

Hassan, M.Z., Osman, H., Ali, M.A., Ahsan, M.J., 2016. Therapeutic potential of coumarins as antiviral agents. Eur. J. Med. Chem. 123, 236-255.

He, W., Zhang, B.L., Zhou, S.Y., Sun, X.L., Zhang, S.Y., 2007. Facile total synthes is of xanthotoxol. Synth. Commun. 37, 361-367.

Ito, A., Shamon, L.A., Yu, B., Mata-Greenwood, E., Lee, S.K., Van Breemen, R.B., Mehta, R.G., Farnsworth, N.R., Fong, H.H.S., Pezzuto, J.M., Kinghorn, A.D., 1998. Antimutage nic constituents of Casimiroa edulis with potential cancer chemopreventive activity. J. Agric. Food. Chem. 46, 3509-3516.

Kang, J., Zhou, L., Sun, J., Han, J., Guo, D.A., 2008. Chromatographic fingerprint analysis and characterization of furocoumarins in the roots of Angelica dahurica by HPLC/DAD/ESI-MS technique. J. Pharm. Biomed. Anal. 47, 778-785.

Karonen, M., Hamalainen, M., Nieminen, R., Klika, K.D., Loponen, J., Ovcharenko, V.V., Moilanen, E., Pihlaja, K., 2004. Phenolic extractives from the Bark of Pinus sylvestris L. and their effects on inflammatory mediators nitric oxide and prostaglandin E2, J. Agric. Food Chem. 52, 7532-7540.

Kasperkiewicz, K., Erkiert-Polguj, A., Budzisz, E., 2016. Sunscrening and photosensitizing properties of coumarin and their derivatives. Lett. Drug Des. Discovery 13, 465-474.

Kitamura, N., Kohtani, S., Nakagaki, R., 2005. Molecular aspects of furocoumarin reactions: photophysics, photochemistry, photobiology and structural analysis. J. Photochem. Photobiol C. 6, 168-185.

Kouichi, M., Takashi, T., Isao, K., Toshihiro, F., Yuki, Y., Kanji, I., 2011. New iridoid diesters of glucopyranose from Linaria canadensis (L). Dum. J. Nat. Med. 65, 172-175.

Kwon, H.C., Lee, K.R., 2001. Phytochemical constituents of Artemisia japonica ssp. littoricola. Arch. Pharm. Res. 24, 194-197.

Lemmich, J., Shabana, M., 1984. Coumarin sulphates of Seseli libanotis. Phytochemistry 23, 863-865.

Matos, J.A., Santana, L., Uriarte, E., Abreu, O.A., Molina, E., Yordi, E.G., 2015. Coumarins An important class of phytochemicals, in: Venketeshwer R(Ed), Phytochemicals. Isolation, characterization and role in human health. IntechOpen, http $/ / d x . d o i . o r g / 10.5772 / 59982$.

Ngwendson, J.N., Bedir, E., Efange, S.M.N., Okunji, C.O., Iwu, M.M., Schuster, B.G., Khan, I.A., 2003. Constituents of Peucedanum zenkeri seeds and their antimicrobial effects. Pharmazie 58, 587-589.

Ozenda, P., 1958. Flore du Sahara septentrional et central. CNRS. p. 356.

Quezel, P., Santa, S., 1963. Nouvelle flore de l'Algérie et des désertiques méridionales. CNRS Paris, edn. Vol. II, p. 666. 
Row, E.C., Brown, S.A., Stachulskib, A.V., Lennarda, M.S., 2006. Synthesis of 8geranyloxypsoralen analogues and their evaluation as inhibitors of CYP3A4. Bioorg. Med. Chem. 14, 3865-3871.

Sarker, S.D., Nahar, L., 2017. Progress in the chemistry of naturally occurring coumarins, in: Kinghorn, A.D., Falk, H., Gibbons, S., Kobayashi, J., (Eds), Progress in the chemistry of organic natural products, Vol 106, Springer Int. 241-304.

Setzer, W.N., Vogler, B., Bates, R.B., Schmidt, J.M., Dicus, C.W., Nakkiew, P., Haber, W.A., 2003. HPLC-NMR/HPLC-MS analysis of the bark extract of Stauranthus perforates. Phytochem. Anal. 14, 54-59.

Song, P-P., Zhao, J., Liu, Z-L., Duan, Y-B., Hou, Y-P., Zhao, C-Q., Wu, M., Wei, M., Wang, N-H., Lv, Y., Han, Z-J., 2017. Evaluation of antifungal activities and structure-activity relationships of coumarin derivatives. Pest Manage. Sci. 73, 94-101.

Spinola, V., Castilho, P.C., 2016. Phytochemical profile, chemotaxonomic studies, and in vitro antioxidant activities of two endemisms from Madeira archipelago: Melanoselium decipiens and Monizia edulis (Apiaceae). Chem. Biodivers. 13, 1290-1306.

Voutquene, L., Lavaud, C., 1999. Cytotoxic polyisoprenes and glycosides of long chain fatty alcohols from Dimocarpus fumatus. Phytochemistry 50, 63-69.

Wang, W., Zhang, X., Zhao, Y., Liu, X., Zhang, Z., Wang, M., 2018. Divergent synthesis of four isomers of 6,7-dihydroxy-3,7-dimethyloct-2-enoic acid, ester and evaluation for the antifungal activity. Chin. Chem. Lett. 29, 1872-1874.

Xiong, Y., Chang, M., Deng, K., Luo, Y., 2016. A new phenolic glycoside and two new monoterpenoid furocoumarins from Aurantii fructus Immaturus. Nat. Prod. Res. 30, 15711576.

Youssef, D., Frahm, A.W., 1995. Constituents of the Egyptian Centaurea scoparia, III. Phenolic constituents of the aerial parts. Planta Med. 61, 570-573.

Zhu, J-J., Jiang, J-G., 2018. Pharmacological and nutritional effects of natural coumarins and their structure-activity relationships. Mol. Nutr. Food Res. 62, 1701073. 
Table 1: ${ }^{1} \mathrm{H}$ NMR data of 1-3 $\left(\mathrm{MeOH}-d_{4}\right) . \delta$ in ppm, $J(\mathrm{~Hz})$ in parentheses.

\begin{tabular}{|c|c|c|c|}
\hline & $\mathbf{1}$ & $\mathbf{2}$ & $\mathbf{3}$ \\
\hline Position & $\boldsymbol{\delta}_{\mathbf{H}}(\boldsymbol{J})$ & $\boldsymbol{\delta}_{\mathbf{H}}(\boldsymbol{J})$ & $\boldsymbol{\delta}_{\mathbf{H}}(\boldsymbol{J})$ \\
\hline 2 & & & $6.40, \mathrm{~d}(9.6)$ \\
\hline 3 & $6.38, \mathrm{~d}(9.6)$ & $6.36, \mathrm{~d}(9.6)$ & $8.05, \mathrm{~d}(9.6)$ \\
\hline 4 & $8.03, \mathrm{~d}(9.6)$ & $8.05, \mathrm{~d}(9.6)$ & $7.59, \mathrm{~s}$ \\
\hline 5 & $7.57, \mathrm{~s}$ & $7.53, \mathrm{~s}$ & $7.91, \mathrm{~d}(2.2)$ \\
\hline 9 & $7.90, \mathrm{~d}(2.2)$ & $7.88, \mathrm{~d}(2.2)$ & $6.97, \mathrm{~d}(2.2)$ \\
\hline 10 & $6.96, \mathrm{~d}(2.2)$ & $6.94, \mathrm{~d}(2.2)$ & $4.61-4.54, \mathrm{~m}$ \\
\hline $1^{\prime}$ & $5.03, \mathrm{~d} \mathrm{br}(7.6)$ & $5.01, \mathrm{dd}(7.2,1.6)$ & $2.56-2.38, \mathrm{~m}$ \\
\hline $2^{\prime}$ & $5.65-5.55, \mathrm{~m}$ & $5.62-5.53, \mathrm{~m}$ & $4.46, \mathrm{ddd}(11.0,8.3,5.7)$ \\
\hline $4^{\prime}$ & $2.24, \mathrm{ddd}(14.2,9.9,4.7)$ & $2.18, \mathrm{ddd}(11.4,9.7,5.3)$ & $2.31-2.19, \mathrm{~m}$ \\
\hline $5^{\prime}$ & $2.08-1.95, \mathrm{~m}$ & $2.09-1.97, \mathrm{~m}$ & $1.89-1.78, \mathrm{~m}$ \\
\hline $6^{\prime}$ & $1.58, \mathrm{dddd}(13.7,9.9,6.9,1.8)$ & $1.52-1.45, \mathrm{~m}$ & $1.50, \mathrm{ddd}(13.6,6.8,3.1)$ \\
& $1.27-1.17, \mathrm{~m}$ & $1.45-1.30, \mathrm{~m}$ & $1.18, \mathrm{~s}$ \\
\hline $8^{\prime}$ & $3.26(\mathrm{dd}, J=10.5,1.8)$ & $3.58, \mathrm{dd}(9.3,3.6)$ & $1.16, \mathrm{~s}$ \\
\hline $9^{\prime}$ & & & $5.05, \mathrm{~s}$ \\
\hline $10^{\prime}$ & $1.10, \mathrm{~s}$ & $1.16, \mathrm{~s}$ & $5.27, \mathrm{~s}$ \\
\hline $1^{\prime \prime}$ & $1.05, \mathrm{~s}$ & $1.03, \mathrm{~s}$ & \\
\hline $2^{\prime \prime}$ & $1.66, \mathrm{~s}$ & $1.67, \mathrm{~s}$ & \\
\hline $3^{\prime \prime}$ & & & $1.36, \mathrm{~s}$ \\
\hline
\end{tabular}


Table 2: ${ }^{13} \mathrm{C}$ NMR data of 1-3 $\left(\mathrm{MeOH}-d_{4}\right) . \delta$ in ppm

\begin{tabular}{|c|c|c|c|}
\hline & 1 & 2 & 3 \\
\hline Position & $\boldsymbol{\delta}_{\mathrm{C}}$ & $\boldsymbol{\delta}_{\mathrm{C}}$ & $\boldsymbol{\delta}_{\mathrm{C}}$ \\
\hline 2 & $162.75, \mathrm{C}$ & $162.67, \mathrm{C}$ & $162.74, \mathrm{C}$ \\
\hline 3 & $114.93, \mathrm{CH}$ & $114.84, \mathrm{CH}$ & $115.04, \mathrm{CH}$ \\
\hline 4 & $146.75, \mathrm{CH}$ & $146.56, \mathrm{CH}$ & $146.75, \mathrm{CH}$ \\
\hline $4 a$ & $117.94, \mathrm{C}$ & $117.64, \mathrm{C}$ & $118.07, \mathrm{C}$ \\
\hline 5 & $115.19, \mathrm{CH}$ & $114.93, \mathrm{CH}$ & $115.01, \mathrm{CH}$ \\
\hline 6 & $127.72, \mathrm{C}$ & $127.47, \mathrm{C}$ & $127.98, \mathrm{C}$ \\
\hline 7 & $150.21, \mathrm{C}$ & $149.80, \mathrm{C}$ & 149.21, C \\
\hline 8 & $132.29, \mathrm{C}$ & $132.10, \mathrm{C}$ & $132.97, \mathrm{C}$ \\
\hline $8 \mathrm{a}$ & $144.98, \mathrm{C}$ & $144.81, \mathrm{C}$ & $144.36, \mathrm{C}$ \\
\hline 9 & $148.48, \mathrm{CH}$ & $148.09, \mathrm{CH}$ & $148.55, \mathrm{CH}$ \\
\hline 10 & $107.96, \mathrm{CH}$ & $107.82, \mathrm{CH}$ & $107.98, \mathrm{CH}$ \\
\hline $1^{\prime}$ & $70.22, \mathrm{CH}_{2}$ & $70.59, \mathrm{CH}_{2}$ & $74.73, \mathrm{CH}_{2}$ \\
\hline $2^{\prime}$ & $120.74, \mathrm{CH}$ & $120.88, \mathrm{CH}$ & $77.98, \mathrm{CH}$ \\
\hline $3^{\prime}$ & $144.95, \mathrm{C}$ & $143.77, \mathrm{C}$ & $149.93, \mathrm{C}$ \\
\hline$\overline{4^{\prime}}$ & $37.66, \mathrm{CH}_{2}$ & $37.45, \mathrm{CH}_{2}$ & $30.69, \mathrm{CH}_{2}$ \\
\hline $5^{\prime}$ & $30.37, \mathrm{CH}_{2}$ & $28.37, \mathrm{CH}_{2}$ & $30.80, \mathrm{CH}_{2}$ \\
\hline $6^{\prime}$ & $77.07, \mathrm{CH}$ & $83.64, \mathrm{CH}$ & $78.97, \mathrm{CH}$ \\
\hline $7^{\prime}$ & $78.32, \mathrm{C}$ & $81.30, \mathrm{C}$ & $73.80, \mathrm{C}$ \\
\hline $8^{\prime}$ & $21.98, \mathrm{CH}_{3}$ & $26.30, \mathrm{CH}_{3}$ & $25.07, \mathrm{CH}_{3}$ \\
\hline $9^{\prime}$ & $21.04, \mathrm{CH}_{3}$ & $23.39, \mathrm{CH}_{3}$ & $25.67, \mathrm{CH}_{3}$ \\
\hline $10^{\prime}$ & $16.46, \mathrm{CH}_{3}$ & $16.79, \mathrm{CH}_{3}$ & $112.11, \mathrm{CH}_{2}$ \\
\hline $1^{\prime \prime}$ & $57.67, \mathrm{CH}_{2}$ & $107.64, \mathrm{C}$ & \\
\hline $2^{\prime \prime}$ & $16.56, \mathrm{CH}_{3}$ & $28.90, \mathrm{CH}_{3}$ & \\
\hline $3^{\prime \prime}$ & & $27.15, \mathrm{CH}_{3}$ & \\
\hline
\end{tabular}




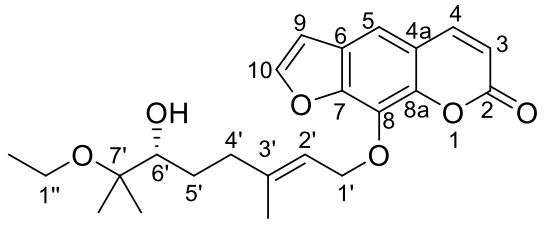

Pituranthosin A (1)

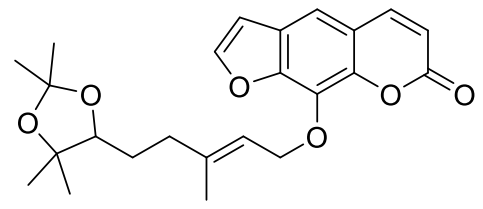

Pituranthosin B (2)

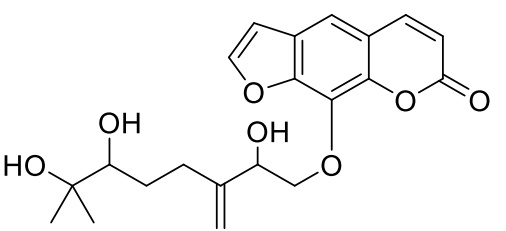

Pituranthosin C (3)

Figure 1. Undescribed furanocoumarins isolated from Deverra battandieri 


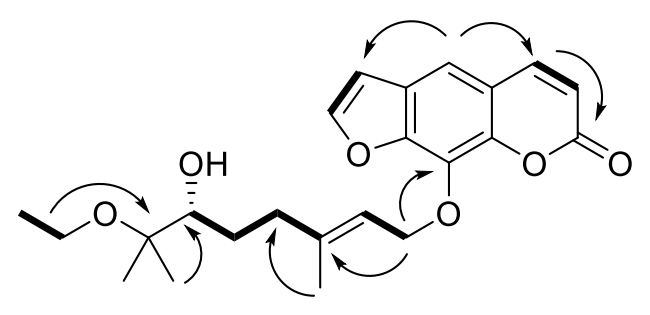

Figure 2. Selected COSY (bold bond) and $\mathrm{HMBC}(\mathrm{H} \rightarrow \mathrm{C})$ correlations for compound $\mathbf{1}$. 

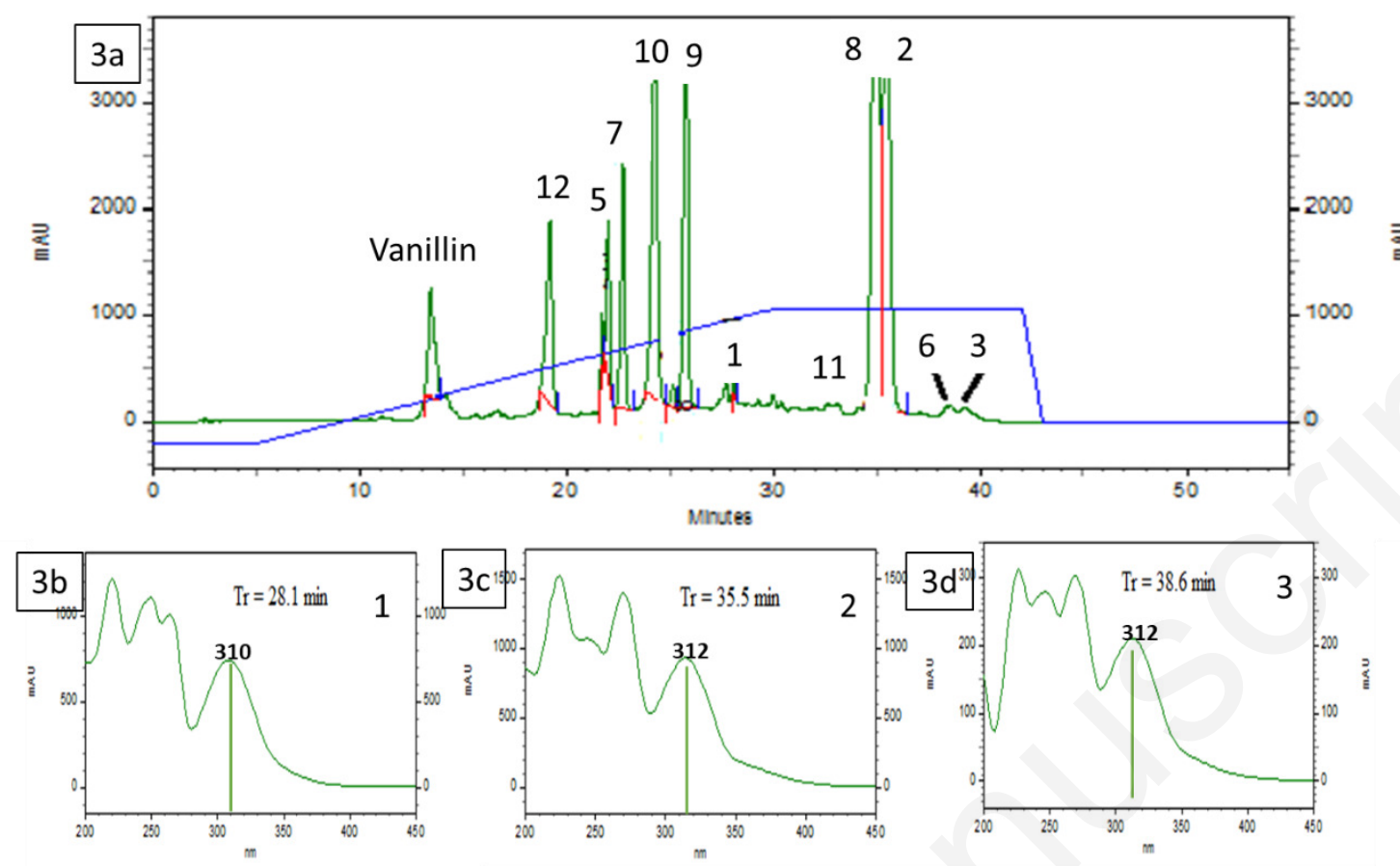

Figure 3. 3a) HPLC/UV (275 nm) chromatographic profile of the $\mathrm{CHCl}_{3}$ extract of the aerial parts of D. battandieri. Column nucleosil HD- $18(5 \mu \mathrm{m}, 250 \times 4.6 \mathrm{~mm})$. Phase: $0.1 \%$ formic acid in milli-Q $\mathrm{H}_{2} \mathrm{O}-$ ACN. Gradient: (10-35-35-10-10 \% ACN) (0-5-30-43-55 min). Flow $1 \mathrm{~mL} . \mathrm{min}^{-1}$; injection volume: 20 $\mu \mathrm{L} ; 3 \mathrm{~b}$ ) UV spectrum of compound 1 ; 3c) UV spectrum of compound 2 ; 3d) UV spectrum of compound 3. 